\title{
FAKTOR YANG BERHUBUNGAN DENGAN PERILAKU MEROKOK PADA REMAJA DI SMP NEGERI 7 LANGGUDU KABUPATEN BIMA
}

\section{Factors Assosiated with Smoking Behaviour Among School Aged Adolescents at Juniour High School Langgudu Bima District}

\author{
Suriaty A Damang, Rosdiana Syakur,Riri Andriani \\ Universitas Indonesia Timur \\ Email : zulhaq101211@gmail.com
}

\begin{abstract}
ABSTRAK
Merokok merupakan masalah yang belum bisa terselesaikan hingga saat ini. Merokok sudah melanda berbagai kalangan, dari anak-anak sampai orang tua, laki-laki maupun perempuan. Tujuan penelitian adalah untuk mengetahui faktor yang berhubungan dengan perilaku merokok pada remaja di SMPN 7 Langgudu Kabupaten Bima terhadap perilaku merokok yang meliputi faktor pengaruh iklan,kontrol orang tua, kontrol diri, teman sebaya, dan sikap di SMPN 7 Langgudu Kabupaten Bima. Jenis penelitian yang digunakan adalah observasional dengan pendekatan cross sectional dengan pengambilan Simple Random Sampling. Hasil penelitian diperoleh bahwa faktor kontrol orang tua $(p 0,000)$, kontrol diri ( 0,001$)$, teman sebaya $(p 0,008)$, dan sikap $(p 0,004)$ berhubungan dengan perilaku merokok pada siswa. Sedangkan faktor pengaruh iklan ( $p 0,154)$ tidak berhubungan dengan perilaku merokok pada remaja. di SMPN 7 Langgudu Kabupaten Bima.
\end{abstract}

Kata Kunci : Perilaku, Iklan, Kontrol orang tua, Kontrol diri, Teman sebaya.

\section{ABSTRACT}

Smoking is a problem that can not be resolved until today. Smoking has hit various groups, from children to the elderly, men and women. The aim of the study was to determine the factors associated with smoking behavior in adolescents at Langgudu Junior High School in Bima District on smoking behavior which includes the influence of advertising, Parental control, self-control, peers, and attitudes at Langgudu Junior High School. The type of research used was observational with a cross sectional approach with taking Simple Random Sampling. The results showed that the factors of parental control ( $p 0,000)$, self control ( $p$ 0,001), peers ( $p 0,008)$, and attitudes $(p$ 0,004) related to smoking behavior in students. While the influence of advertising factors ( $p$ 0.154) is not related to smoking behavior in adolescents at Langgudu Junior High School Bima District.

Key Word : Behaviour, Advertising, Parental Control, Self Control, Peers. 


\section{PENDAHULUAN}

Merokok merupakan masalah yang belum bisa terselesaikan hingga saat ini. Merokok sudah melandah berbagai kalangan, dari anak-anak sampai orang tua, laki-laki maupun perempuan. Rokok merupakan zat psikoaktif berbaha yang mengandung 4000 zat kimia, dan 20 macam diantaranya merupakan racun yang mematikan (Hartini et al, 2014). Menurut WHO (2008) terdapat 10 negara dengan jumlah perokok terbesar didunia salah satunnya merupakan Indonesia dengan urutan ketiga setelah China dan India. Tabocca Atlas (2012) melaporkan bahwa sekitar 35\% perokok laki-laki berasal dari Negara maju dan $50 \%$ dari Negara berkembang. Dalam satu dekade yang lalu sedikitnya 50 juta orang telah meninggal akibat mengidap penyakit karena tembakau. Apabila hal tersebut tidak ditanggulagi maka akan diperkirakan 1 milyar nyawa akan terenggut pada abad ke 21 . Sebagian besar terjadi di Negara-negara berpenghasilan menengah dan miskin merupakan sekitar $80 \%$ kematian, termasuk Indonesia (Fauzi et al., 2013) ${ }^{1,2}$.

Data dari riset kesehatan Dasar (2013) menunjukkan bahwa 50\% dari penduduk Indonesia mulai konsumsi rokok pada usia 15-19 tahun, dan sekitar 9\% mulai merokok pada usia 10-14 tahun, konsumsi rokok pada masa remaja diyakini sebagai gerbang awal untuk menyalah gunakan obat lain dikemudian hari. Perevalensi perokok di Indonesia (baik perokok hisap maupun penguyah tembakau) pada kelompok umur $\geq 15$ tahun cenderung meningkat setiap tahunnya. Pada tahun 2007 sebesar 34,7\% tahun 2010 meningkat menjadi 34,7\% dan tahun 2013 mencapai 36,3\% (Riskesdas, 2013) ${ }^{3}$.

Menurut Global Aduts Tobacco Survey (GATS, 2011). Indonesia memiliki jumlah perokok aktif terbanyak dengan prevalensi $67 \%$ laki-laki dan 2,7\% pada wanita atau $34,8 \%$ penduduk (sekitar 5,9 juta orang) dan $85,4 \%$ masyarakat terpapar asap rokok ditempat umum. Dan Indonesia merupakan Negara dengan jumlah perokok laki-laki terbesar dunia yaitu $14 \%$ sejak 17 tahun (DEPKES, 2012) ${ }^{3}$.

Faktor-faktor yang mempengaruhi kebiasaan merokok merupakan tekanan teman sebaya, berteman dengan perokokusia muda, status sosial ekonomi rendah, mempunyai orang tua merokok, saudara kandung, lingkungan sekolah ( guru)yang merokok dan tidak percya bahwa merokok mengganggu kesehatan. Peniltian lain diindonesia dilakukan oleh Global Tabacco Survey (GTYS) atau survei merokok pada remaja di Jakarta menujukkan perilaku merokok karena lingkungan keluarga 66,85\% tinggal dengan keluarga yang merokok dan $93,2 \%$ karena faktor media atau atau melihat iklan rokok dimedia ( Tarwoto 2013) $)^{3}$.

Alasan remaja merokok didepok, jawa barat karena melihat teman $28,43 \%$, melihat orang tua $9,8 \%$, menghilangkan stress $3,92 \%$ dan tidak pernah mendapatkan informasi tentang bahaya merokok 10,79\% supriadin 2014.

Provinsi Nusa Tenggara Barat khususnya pilau Lombok merupakan pensuplai ratarata $80 \%$ produk tembakau Virginia nasional setiap tahun Menurut catatan Dinas Perkebunan Provinsi NTB (2012).

NTB lebih dari separoh penduduknya tidak merokok yang terdiri dari mantan perokok $1,9 \%$ dan bukan perokok $68 \%$. Proporsi penduduk di atas 10 tahun yang merokok tiap hari di Provinsi NTB rata-rata 25,5\%, tertinggi ada di kabupaten Sumbawa 27,7\% dan Lombok Tengah 27,5\%, sedangkan yang terendah di Kota Bima 20,9\%. Proporsi tertinggi penduduk tidak merokok ada di Kota Bima 75,4\% dan terendah adadi Kabupaten Lombok tengah $66,8 \%$ riskesdas (2007).

Berdasarkan uraian di atas, maka peneliti tertarik untuk melakukan penelitian, untuk mengetahui faktor-faktor yang berhubungan dengan perilaku merokok pada remaja di SMP Negeri 7 langgudu Kabupaten Bima.

\section{METODE PENELITIAN}

Jenis penelitian ini merupakan penelitian kuantitatif dengan rancangan survei analitik dengan pendekatan cross sectional study penelitian yang bertujuan untuk menyajikan tentang hubungan antara variabel independen dengan variabel dependen (Sugiyono, 2010). 
HASIL PENELITIAN

Tabel 1.

Hubungan Pengaruh Iklan Dengan Perilaku Merokok Siswa Laki-Laki di SMPN 7 Langgudu Kabupaten Bima

\begin{tabular}{|c|c|c|c|c|c|c|}
\hline \multirow{3}{*}{$\begin{array}{l}\text { Pengaruh } \\
\text { Iklan }\end{array}$} & \multicolumn{4}{|c|}{ Perilaku Merokok } & \multirow{3}{*}{ Jumlah } & \multirow{3}{*}{$\mathbf{P}$} \\
\hline & \multicolumn{2}{|c|}{$\begin{array}{c}\text { Tidak } \\
\text { Merokok }\end{array}$} & \multicolumn{2}{|c|}{ Merokok } & & \\
\hline & $\mathbf{n}$ & $\%$ & $\mathbf{n}$ & $\%$ & & \\
\hline $\begin{array}{c}\text { Tidak } \\
\text { Mengetahui }\end{array}$ & 14 & 46,7 & 16 & 53,3 & 30 & 0154 \\
\hline Mengetahui & 5 & 26,3 & 14 & 73,3 & 19 & \\
\hline Jumlah & 19 & 38,8 & 30 & 61,2 & 49 & \\
\hline
\end{tabular}

Tabel 1 menunjukan bahwa dari 19 siswa terhadap pengaruh iklan yang tidak mempengaruhi tidak merokok sebanyak $46,7 \%$. Sedangkan dari 30 siswa yang pengaruhi ikln mempengaruhi tidak merokok sebanyak $26,3 \%$

Hasil analisis statistic chi square diperoleh nilai p 0,154>a=0,05 ini menunjukan bahwa tidak ada hubungan antara perilaku merokok dengan pengaruh iklan di SMPN 7 Langgudu Kabupaten Bima.

Tabel 2.

Hubungan kontrol orang tua dengan perilaku merokok siswa laki-laki di SMPN 7 Langgudu Kabupaten Bima

\begin{tabular}{|c|c|c|c|c|c|c|}
\hline \multirow{2}{*}{$\begin{array}{c}\text { Kontrol Orang } \\
\text { Tua }\end{array}$} & \multicolumn{3}{|c|}{ Perilaku Merokok } & \multirow{2}{*}{ Jumlah } & \multirow{2}{*}{$\begin{array}{c}\text { Tidak } \\
\text { Merokok }\end{array}$} & \multicolumn{2}{|c|}{ Merokok } & & P \\
\cline { 2 - 6 } & $\mathbf{n}$ & $\%$ & $\mathbf{n}$ & $\%$ & & \\
\hline Kurang Baik & 3 & 10,7 & 25 & 89,3 & 28 & \multirow{2}{*}{0,000} \\
Baik & 16 & 76,2 & 5 & 23,8 & 21 & \\
\hline \multicolumn{1}{|c|}{ Jumlah } & 19 & 38,8 & 30 & 61,2 & 49 & \\
\hline
\end{tabular}

Tabel 2 menunjukan bahwa dari 28 siswa dengan kontrol orang tua kurang baik terdapat yang tidak merokok sebanyak 10,7\%. Sedangkan dari 21 siswa dengan kontro orang tua baik terdapat yang tidak merokok sebanyak $76,2 \%$

Hasil analisis statistik chi square diperoleh $p=0,000<a=0,05$ ini menunjukan bahwa ada hubungan antara kontrol orang tua dengan perilaku merokok di SMPN 7 Langgudu Kabupaten Bima. 
Tabel 3.

Hubungan kontrol diri Dengan Perilaku Merokok Siswa Laki-Laki di SMP Negeri 7 Langgudu Kabupaten Bima

\begin{tabular}{|c|c|c|c|c|c|c|}
\hline \multirow{3}{*}{$\begin{array}{c}\text { Kontrol } \\
\text { Diri }\end{array}$} & \multicolumn{4}{|c|}{ Perilaku Merokok } & \multirow{3}{*}{ Jumlah } & \multirow{3}{*}{$\boldsymbol{P}$} \\
\hline & \multicolumn{2}{|c|}{$\begin{array}{c}\text { Tidak } \\
\text { Merokok }\end{array}$} & \multicolumn{2}{|c|}{ Merokok } & & \\
\hline & $\mathrm{n}$ & $\%$ & $\mathrm{n}$ & $\%$ & & \\
\hline Rendah & 18 & 54,5 & 15 & 45,5 & 33 & \\
\hline Tinggi & 1 & 6,2 & 15 & 93,8 & 16 & 0,001 \\
\hline Jumlah & 19 & 38,8 & 30 & 61,2 & 49 & \\
\hline
\end{tabular}

Tabel 3 menunjukan bahwa dari 33 siswa dengan kontrol diri rendah terdapat yang tidak merokok sebanyak 54,5\%. Sedangkan dari 16 siswa dengan kontrol diri tinggi terdapat yang tidak merokok sebanyak $6,2 \%$. Berdasarkan hasil uji statistic chi square dengan hasil $\mathrm{p}=0,001<\mathrm{a}=0,05$ sehingga Ha diterima dan Ho ditoiak dan dapat ada hubungan antara kontrol diri dengan perilaku merokok di SMP Negeri 7 Langgudu Kabupaten Bima.

Tabel 4.

Hubungan Teman Sebaya Dengan Perilaku Merokok Siswa Laki-Laki di SMP Negeri 7 Langgudu Kabupaten Bima

\begin{tabular}{|c|c|c|c|c|c|c|}
\hline \multirow{3}{*}{$\begin{array}{c}\text { Teman } \\
\text { Sebaya }\end{array}$} & \multicolumn{3}{|c|}{ Perilaku Merokok } & \multirow{2}{*}{$\begin{array}{c}\text { Tidak } \\
\text { Merokok }\end{array}$} & \multicolumn{2}{|c|}{ Merokok } \\
& Jumlah & \multirow{2}{*}{$P$} \\
\cline { 2 - 6 } & $\mathrm{n}$ & $\%$ & $\mathrm{n}$ & $\%$ & & \multirow{2}{*}{} \\
\hline Resiko tinggi & 18 & 50,0 & 18 & 50,0 & 36 & \multirow{2}{*}{0,008} \\
Resiko Rendah & 1 & 7,7 & 12 & 92,3 & 13 & \\
\hline Jumlah & 19 & 38,8 & 30 & 61,2 & 49 & \\
\hline
\end{tabular}

Tabel 4 menunjukkan bahwa dan 36 siswa dengan teman sebaya resiko tinggi terdapat yang tidak merokok sebanyak $50,0 \%$. Sedangkan dari 13 siswa teman sebaya resiko rendah terdapat yang merokok sebanyak $7,7 \%$

Berdasarkan hasil uji statistic chi square dengan hasil $\mathrm{p}=0,008<\mathrm{a}=0,05$ sehingga $\mathrm{Ha}$ diterima dan Ho ditolak dan dapat disimpulkan ada hubungan antara kontrol diri dengan perilaku merokok di SMP Negeri 7 Langgudu Kabupaten Bima.

Tabel 5.

Hubungan Sikap Dengan Perilaku Merokok Siswa Laki-Laki di SMP Negeri 7 Langgudu Kabupaten Bima

\begin{tabular}{|c|c|c|c|c|c|c|}
\hline \multirow{2}{*}{ Sikap } & \multicolumn{3}{|c|}{ Perilaku Merokok } & \multirow{2}{*}{} & \multirow{2}{*}{$\begin{array}{c}\text { Tidak } \\
\text { Merokok }\end{array}$} & \multicolumn{2}{|c|}{ Merokok } & Jumlah & P \\
\cline { 2 - 5 } & $\mathrm{n}$ & $\%$ & $\mathrm{n}$ & $\%$ & & \\
\hline Sikap Negatif & 19 & 48,7 & 20 & 51,3 & 39 & \multirow{2}{*}{0,004} \\
Sikap Positif & 0 & 0,0 & 10 & 100,0 & 10 & \\
\hline Jumlah & 19 & 38,8 & 30 & 61,2 & 49 & \\
\hline
\end{tabular}


Tabel 5 menunjukan bahwa dari 39 siswa dengan sikap positif terdapat yang tidak merokok sebanyak $48,7 \%$. Sedangkan dari 1 siswa laki-laki yang sikap negatif terdapat yang merokok sebanyak $0,0 \%$

Berdasarkan hasil uji statistic chi square dengan hasil $\mathrm{p}=0,004<\mathrm{a}=0,05$ sehingga $\mathrm{Ha}$ diterima dan Ho ditolak dan dapat disimpulkan ada hubungan antara sikap dengan perilaku merokok di SMP Negeri 7 Langgudu Kabupaten Bima.

\section{PEMBAHASAN}

1. Hubungan antara pengaruh iklan dengan perilaku merokok

Iklan rokok senantiasa menampilkan bahwa perokok adalah lambang kejantanan yang membuat remaja sering kali terpicu untuk mengikuti perilaku seperti iklan tersebut. Remaja rawan untuk terpengaruhi iklan karena iklan rokok dapat menjadi instrument dalam masa inisiasi remaja untuk merokok. masa inisiasi merupakan tahapan yang kritis pada seorang individu karena merupakan tahap coba-coba dimana ia beranggapan bahwa dengan merokok ia terlihat dewasa sehingga ia akan memulai dengan mencoba dengan beberapa batang rokok.

Iklan merokok berhasil mempersuasi remaja sehingga remaja merasa merokok itu merupakan ha! yang umum, wajar, dan sangat biasa dilakukan. Remaja yang sedang berada dalam masa pembentukan jati diri tentunya akan tertarik dengan citra positif yang ditawarkan dalam iklan rokok. Paparan iklan rokok akan mendorong remaja untuk merokok sebagain wujud jati diri yang hendak dibentu olehnya.

Dari hasil penelitian yang menunjukan didapatkan bahwa pengaruh iklan tidak mempengaruhi perilaku merokok yang tidak merokok sebanyak $46,7 \%$. Sedangkan yang di pengaruhi oleh iklan terdapat yang tidak merokok sebanyak $26,3 \%$ pengaruh iklan diperoleh dari proses tidak tahu menjadi tahu dengan melakukan proses pembelajaran, penerimaan materi, bahan ajaran, dan pengalaman serta kemampuan menganalisa.

Dari hasil penelitian 53,3\% siswa yang merokok dengan pengaruh iklan yang tidak mempengaruhi terhadap perilaku merokok, tetapi ada yang tidak merokok karna ada sebagian siswa jika mereka nonton tv sepulang sekolah mereka lebih menyukai nonton film karton di bandingkan melihat iklan-ikian tentang rokok dan mereka jarang bergaul dengan teman-temannya sehingga mereka tidak terpengaruh dengan hasutanhasutan yang ada dilingkungan sekitar.

Sedangkan dari $26,3 \%$ siswa yang tidak morokok dengan pengaruh iklan yang mempengaruhi terhadap perilaku merokok tetapi masih ada yang merokok kama para remaja sekarang hanya ingin terlihat keren di lingkungan sekitar dampa mereka menyadari bahwa merokok itu sangat berbahaya bagi tubuh mereka, sehingga mereka mengebaikan tentang poster-postef yang ada di bungkus rokok karena mereka merasa dengan merokok mereka akan terlihat dewasa.

Untuk mengetahui adanya hubungan antara pengaruh iklan terhadap perilaku merokok, dari hasil uji chi squere didapatkan nilai $p=0,139$ maka dapat disimpulkan tidak ada hubungan pengaruh iklan terhadap perilaku merokok pada siswa laki-laki SMP Negeri 7 Langgudu Kabupaten Bima.

1. Hubungan control orang tua dengan perilaku merokok

Dalam Jounal of Consumen Affairs, menyebutkan bahwa orang tua perokok akan berpengaruh dalam mendorong anak mereka untuk menjadi perokok pemula diusia siswa. Diperkirakan pengaruh orang tua ini akan meningkatkan kemungkinan untuk merokok.

Orang tua merupakan contoh dan model bagi remaja, namun bagi orang tua yang kurang tau tentang kesehatan secara tidak langsung mereka telah mengajarkan perilaku atau pola hidup yang kurang sehat. Banyaknya remaja yang merokok salah satu pendorongnya merupakan dari pola asuh orang tua mereka yang kurang baik, contohnya saja perilaku orang tua yang merokok dan perilaku tersebut dicontoh oleh anak - anaknya secara turun - menurun 
Dalam lingkungan keluarga kontrol orang tua itu sangatiah penting. Oranng tua yang memberikan kelonggaran dan memberikan kebebasan terhadap anaknya kemungkinan akan berpengaruh terhadap lingkungan sekitar.

Dari hasil penelitian yang menunjukan kontrol orang tua kurang baik terdapat yang tidak merokok sebanyak $10,7 \%$. Sedangkan dengan kontrol orang tua balk terdapat yang tidak merokok sebanyak $76,2 \%$ Kontrol orang tua yang baik maka memberikan hasil yang baik dalam lingkungan keluarga

Dari hasil peniiitian $89,3 \%$ siswa yang merokok dengan kontrol orang tua kurang baik terhadap perilaku merokok, tetapi ada yang tidak merokok karna pengetahuan yang dimiliki oleh siswa tentang bahaya merokok dan kandungan-kandungan yang ada dalam rokok membuat mereka tidak ingin merokok waiaupun orang-orang disekirnya meberikan dia rokok tetapi dia menolaknya.

Sedangkan $76,2 \%$ siswa yang tidak merokok dengan kontrol orang tua yang baik terhadap perilaku merokok, tetapi masih ada yang merokok karna ada sebagian siswa yang kontrol orang tuannya baik tetapi mereka tetap merokok karena mereka ingin terihat keren tampa memikirkan bahaya akan rokok dan pengetahuan tentang bahaya merokokmasih kurang.

Berdasarkan keterangan diatas perilaku merokok kontrol orang tua yang baik, hal ini dapat terjadi karena mereka inggin terlihat dewasa/keren. Tampa menghiraukan araara yang di berikan orang tuanya.

Untuk mengetahui adanya hubungan antara kontrol orang tua terhadap perilaku merokok, dari hasil uji chi square didapatkan nitai $P=0,000$ maka dapat disimpulkan ada hubungan kontrol orang tua terhadap perilaku merokok pada siswa laki-laki SMP Negeri 7 Langgudu Kabupaten Bima.

Penilitian ini sejalan dengan penilitian yang dilakukan oleh Runi Rahmatia 2013 menyatakan bahwa ada hubungan bermakna antara kontrol orang tua dengan perilaku merokok dengan nilai $P=0,003$ '

2. Hubungan Antara Kontrol Dtri Dengan Perilaku Merokok

Kontrol diri sebagai proses yang menjadikan individu sebagai aken utama dalam memandu, mengarahkan dan mengatur perilaku utamanya yang dapat membawa kearah konsekuensi posistif. Ada individu yang memiliki kontrol diri yang tinggi dan ada yang memiliki kotrol diri yang rendah. Remaja yang memiliki kotrol diri yang tinggi pada umumnya masih dapat mengontrol dorongan-dorongan yang ada dalam dirinya, sehingga mampu mengendalikan perilaku merokoknya tetap rendah bahkan tidak ada. Begitu pula sebaliknya remaja yang memiliki kontrol diri rendah tidak mampu melepaskan diri dari dorongan-dorongan untuk merokok dan secara turus-menerus terjadi peningkatan jumlah rokok yang dihisap tiap hari, tampa ada mempertimbangkan akibat-akibat negatif yang ditimbulkan, baik terhadap dirinya sendiri maupun orangorang disekitarnya.

Dari hasil penilitian yang menunjukan kontrol diri rendah dengan perilaku merokok terdapat yang tidak merokok sebanyak 54,5\%. Sedangkan kontrol diri tinggi terdapat yang tidak merokok sebanyak 6,2\%

Dari hasii penifitian $45,5 \%$ dengan kontrol diri rendah terhadap perilaku merokok tetapi masih ada yang tidak merokok karna mereka mampu mengontrol diri terhadap pengaruh lingkungan sekitar dan mereka sangat memahami bahwa rokok itu sangat berbahaya.

Sedangkan $6,2 \%$ dengan kontrol diri tinggi terhadap perilaku merokok tetapi masih ada yang merokok karna mereka tidak mampu mengontrol dirinya sehingga mereka sangat cepat terpengaruh oleh lingkungan sekitar untuk merokok dampa mereka sadari bahwa merokok itu berbahaya bagi diri mereka. Berdasarkan hasii analisa statistik Chi-Square menunjukkan bahwa ada hubungan antara kontrol diri dengan perilaku merokok siswa sekolah menengah pertama negeri 7 langgudu kabupaten bima.

Penilitian ini sejalan dengan penilitian yang dilakukan oleh Gretty C. Runtukahu 2015 menyatakan bahwa ada hubungan antara kontrol diri dengan perilaku merokok pada remaja dengan nilai $P=0,00$ 
3. Hubungan Teman Sebaya Dengan Perilaku Merokok

Berbagai fakta mengungkapkan bahwa semakin banyak remaja merokok maka semakin besar kemungkinan teman-temannya adalah perokok juga dan demikian sebaliknya. Dari fakta tersebut ada kemungkinan remaja terpengaruh oleh temantemannya.

Dari Hasil peniiitian yang menunjukan teman sebaya resiko tinggi terhadap perilaku merokok terdapat yang tidak merokok sebanyak 50,0\%. Sedangkan teman sebaya resiko rendah terhadap perilaku merokok terdapat yang tidak merokok sebanyak $7,7 \%$

Teman sebaya mampu memberikan nilai positif pada remaja tersebut dengan memberikan informasi-informasi mengenai pembadingan identitas dirinya. Remaja yang panadai menempatkan dirinya pada lingkungan teman sebaya yang baik dapat mengembangkan identitas dirinya yang positif. mengetahui adanya hubungan antara teman sebaya terhadap perilaku merokok pada siswa laki-laki SMP Negeri 7 Langgudu Kabupaten Bima.

Penelitian ini sejalan dengan penelitian yang dilakukan oleh harlino 2016 menyatakan bahwa ada hubungan teman sebaya dengan perilaku merokok pada remaja dengan nilai $p=0,001$.

4. Hubungan sikap dan perilaku merokok

Sikap merupakan mekanisme mental yang mengevaluasi, membentuk pandang, mewarnai perasaan dan akan ikut menentukan kecenderungan perilaku individu, bahkan terhadap diri individu itu sendiri disebut fenomena sika. Fenomena sikap yang timbul tidak saja ditentukan oleh keadaan objek yang sedang dihadapi tetapi juga dengan kaitannya dengan pengalaman-pengalaman masa lalu, oleh situasi saat sekarang, dan oleh harapan-harapan untuk masa yang akan datang.

Dari hasil penilitian menunjuka sikap negatif terdapat yang tidak merokok sebanyak $48,7 \%$. Sedangkan sikap positif terdapat yang tidak merokok sebanyak $0,0 \%$

Dari hasil penilitian didapatkan pada umumnya siswa $(92,7 \%)$ mempunyai sikap yang positif terhadap perilaku merokok, hasil ini sama dengan penilitian yang dilakukan oleh ulvia (2011) di kota padang yang mendapatkan 90,8\% siswa dengan sikap positif terhadap perilaku merokok.

Secara keseluruhan siswa setuju bahwa perilaku merokok adalah tindakan yang negatif terhadap perilaku merokok yaitu 7,3\%. Dari hasil yang didapatkan, terlihat bahwa ada sebagian siswa yang cenderung ingin diberi kebebasan untuk merokok, hal ini sesui dengan teori Richmond dan sklansky dalam sarwono SW 2011.

Mengetahui adanya hubungan antara sikap terhadap perilaku merokok pada siswa laki-laki SMP Negeri 7 Langgudu Kabupaten Bima.

\section{KESIMPULAN}

Berdasarkan hasil penelitian yang telah dilaksanankan dapat disimpulkan bahwa ada hubungan antara kontrol orang tua, kontrol diri, teman sebaya, dan sikap terhadap perilaku merokok pada siswa laki-laki, namun tidak ada hubungan antara pengaruh iklan terhadap perilaku merokok Siswa laki-laki SMPN 7 Langgudu Kabupaten Bima.

\section{DAFTAR PUSTAKA}

Angelina DY, Matulessy A.(2013). pola asuh otoriter kontrol diri Dan perilaku Seks Bebas Remaja

Ariani, R., (2010). Kesehatan remaja : problem dan solusinya, Jakarta : salemba medika

Agun, Andi (2010). Hubungan antara dukungan orang tua, teman sebaya, dan iklan rokok dengan perilaku merokok pada siswa universitas muhammadiyah Surakarta. 
Azwar, A (2013). Beberapa sikap yang terdapat pada Individu.

Cahyani, B. (2013). Hubungan antara Presepsi terhadap Merokok dan Kepercayaan Diri dengan Perilaku Merokok pada Siswa.

Depkes (2012). Faktor Tembakau dan Permasalahannya di Indonesia Thun 2012. Jakarta: Tobacco Control Support Center-Ikatan Ahli Kesehatan Masyarakat Indonesia.

Fauzi, R, Mohammad, K, Antojo, A, Soewarso, K. dan Zkiyah (2013). Atlas Tobacco Control Support Center-lkatan Ahli Kesehatan Masyarakat Indonesia.

Faudah, M. (2012). Faktor-faktor yang mempengaruhi perilaku merokok.

Kemenkes (2013). Riset Kesehatan Dasar 2013. Jakarta : badan peneiltian dan pengembangan Kesehatan.

Kemenkes,( 2013). Peraturan Menteri Kesehatan Republik Indonesia Nomor 28 tahun 2013 tentang pencanturan Peringatan Kesehatan Dan Informasi Kesehatan Pada Kemasan Produk Tembakau. Jakarta Kemenkes RI.

Maseda, D, R, Suba, B. Dan Wongkar, D.( 2013.) Hubungan dan sikap tentang Bahaya Merokok Dengan Perilaku Merokok pada Remaja. Ejournal Keperawatan.

Mu'tadin, Z (2012). Kementrian sebagai kebutuhan psikologipada remaja.

Mukuan, S, E,( 2012). Hubungan antara pengetahuan dan sikap tentang bahaya merokok bagi kesehatan dengan tindakan meroko..

Naingolan, T. (2010). Metodologi peniltian kesehatan.

Notoatmodjo, S. (2013), Promosi kesehatan dan ilmu perilaku

Notoatmojo (2011). Pendidikan, perilaku dan promosi kesehatan.

Pakaya, S. (2013). Hubungan pengetahuan tentang Bahaya merokok dengan perilaku merokok

Ramdhan M,(2013). penerapan tehnik kontrol diri untuk menguragi konsumsi rokokpada kategori perokok ringan.

Susanto, D. N. (2013). Hubungan antara dukungan negatif orang tua dengan perilaku merokok pada remaja.

Shohibullana IH.(2014) Kontrol dan perilaku konsumtif pada siswaSMP Tinjauan dari sekolah.

Sumarna, R.(2012). Pengetahuan, sikap, dan perilaku merokok.

Tarwoto. (2010). Kesehatan remaja problem dan solusinya, Jakarta: Salemba Medika.

Ulhaq MZ.,(2014) Komolohadi RAR. Hubungan antara kontrol diri dengan perilaku merokok pada siswa siswi.

Wahyuni, E. (2010). Hubungan pengetahuan, ayah yang merokok, dan uang saku terhadap kebiasaan merokok pada remaja.

WHO. (2012) GATS (Global Adult Tabacco Survey)

WHO .(2015). Global Youth Tabacco Survey (GYTS) : Indonesia report 2014,

Wawan, A. dan dewi,(2012) teori dan pengukuran pengetahuan, sikap dan perilku manusia. Yogyakarta : Nuha Medika. 